\title{
RBX1 wt Allele
}

National Cancer Institute

\section{Source}

National Cancer Institute. RBX1 wt Allele. NCI Thesaurus. Code C51303.

Human RBX1 wild-type allele is located in the vicinity of 22q13.2 and is approximately 21

$\mathrm{kb}$ in length. This allele, which encodes RING-box protein 1 , is involved in ubiquitination and protein degradation. 